\title{
Til hverdag og fest
}

\author{
Distriktslegen i Oppdal redegjør i flere artikler for forholdene på stedet. I Tidsskriftet nr. 6/1933 tar han blant \\ annet for seg matstellet og de forskjellige måltidene. Fremstilling og bruk av de mange melkebaserte rettene \\ beskrives nøye. Det tradisjonelle kostholdet er på vikende front - ulempen er at bløtt kjøpebrød med sirup \\ ødelegger barnas tenner og at kaffen fortrenger melken. Den enkle kosten står i kontrast til de staselige \\ husene i bygda (Tidsskr Nor Lægeforen 1933; 53: 308-20).
}

\section{Tilbakeblikk på de hygieniske forhold i Opdal lagedistrikt for årene 1907 til 1931.}

\author{
Av distriktslæge Peter L. Nissen, Opdal. \\ (Forts.)
}

Kostholdet i en landsbygd vil vesentlig avhenge av to faktorer - tradisjon og kommunikasjonsforholdene, og den siste faktor av disse er det, som mest har forandret kostholdets art. Før levde man mere enn nu av gårdens egne produkter. - Mest og først har vel dette vist sig for melspisenes vedkommende. Det hårde flatbrød (byggbrød) brukes nok ennu, men det er trengt $\mathrm{i}$ bakgrunnen for det bløte brød av finsiktet rugmel. Ennu verre er det at dette bløte brød gjerne tilsettes med sirup, som gjør det klissent. Dette har gått ut over befolkningens tenner, som er i den slettest mulige forfatning. Den første blivende tann angripes snart, og når barnene $\mathrm{i} 7$ års alderen kommer på skolen, er denne og flere tenner dårlige. Jeg har ennu ikke sett et eneste skolebarn med helt friske tenner.

Alle handelsmenn selger nu brødvarer ; men grovt brød av sammalt rug kan ikke fåes kjøpt uten at det er tilsatt med sirup. «Hyllekaku», som er et ugjæret brød bestående av en byggmelsjevning stekt på ovnshyllen, brukes av og til.

Med innførelse av separator, som nu finnes på enhver gård, og oprettelse av meierier er bruken av melk i husholdningen mindre enn før, især da kaffen blev en almindelig drikk også for de mindre barn. Det ser dog ut til, at man kan få ende på dette misbruk av kaffe til barn siden skolebarnsundersøkelsene er kommet igang, da de hygieniske råd til barnene påtaler denne uskikk og barnene selv villig vil følge rådene.

De gamle melkeretter brukes av ovennevnte grunner mindre, men man får da se dem, for eksempel ved gravøl eller brylupper. Først har vi de forskjellige sorter myser og derav lagede saker. Den søte myse (mussu) kokes inn til mysost mens den ved løpen (løpferment) utskilte ost presses til kvitost.

Mussusmør er mysost som er blandet med vann inntil den blir tynn og så tilsatt litt jevning. - Dette mussusmør legges ofte som et stort smørøie på grøten (byggmelsgrøten) til å dyppe skjebetene i (kalles «stikkels»).

Som en meget yndet rett får man i nesten alle gravøl den såkalte «mæels», innkokt søt mussu inntil den begynner å bli rødlig, hvorefter den utfeldte ost tilsettes og det hele får et lite opkok ; osten flyter da som rødlige klumper i denne suppelignende mussu. Innkokes det hele til det blir grøtet og fast, får vi den såkalte «gubb». - Løpsunn er søt melk, som først er kokt og siden sprengt med sur melk ; den brukes ved siden av for eksempel spekemat.

Fisk var lite brukt før 1920, det var næsten bare som lutefisk eller som spekesild. Nu bringer fiskebiler omtrent året rundt fisk m. m. til bygden. Det er hermed blitt mere variasjon i kostholdet. Grønnsaker er lite brukt, mest kun i form av litt gulerøtter eller kålrabi.

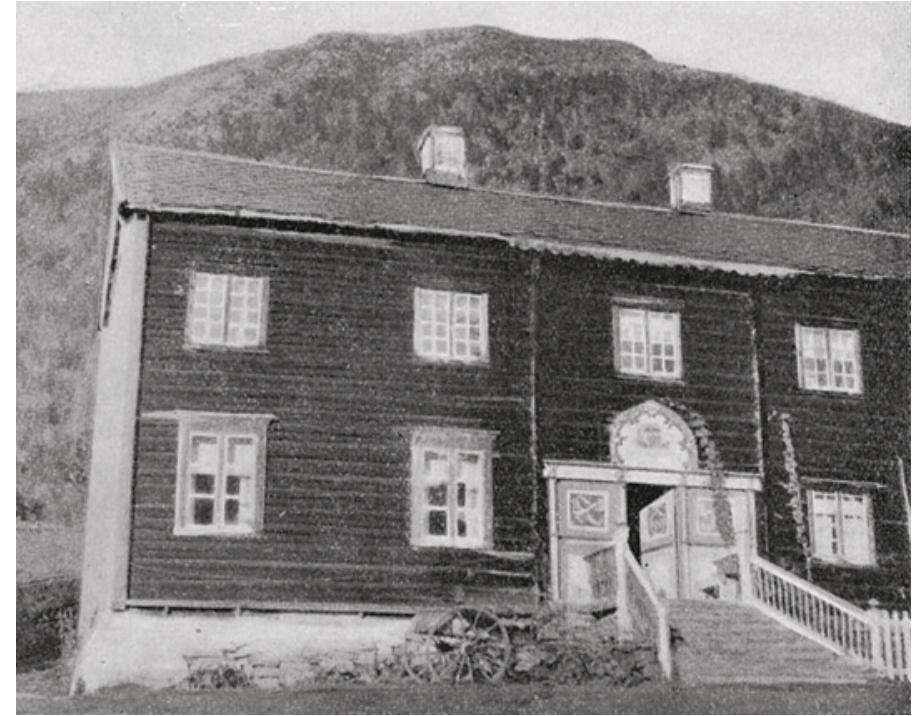

Måltidene er for tiden følgende:

Fyri-åbit kl. 7: Kaffe og smørbrød.

Åbit kl. 10: Havre eller bygg-grøt (av melk eller vann) med spekeflesk og flatbrød. Melkesuppe med smørbrød.

Middag kl. 2: Kjøtt eller fiskerett (til fisken brukes alltid koldt smør) - så er der middagshvil til kl. $1 / 24$, da kaffe og smørbrød.

Kveldsmat kl. 7: Melk og brød, grøt og melk.

Den eldre spisetid - non - kl. 4 var før omtrent som den nuværende middag, og da spiste man en grøtmiddag kl. 12 ; men fyri-åbit var da kl. ${ }^{1 / 2} 6$ om morgenen.

Man stod altså tidligere op og hadde et måltid mere.

Der brukes nok en del margarin til stekning, men som smør på brød er det ikke likt, ja man har endog fordom imot det.

Hvad selve matens tilberedning angår er der derimot skjedd store fremskritt i de senere år. Det er nu meget almindelig at de unge gårdmannsjenter går inn på en husholdningsskole og derfra bringer hjem forandringer i matstellet, som før var ganske ensformig og nokså primitivt.

Matlagningskurser, fiskekurser, ja også grønnsakkurser har enkelte år vært holdt på forskjellige steder i bygden, og de søkes gjerne. 